\title{
Children's physical activity and the preschool physical environment
}

Citation for published version (APA):

Maatta, S., Gubbels, J., Ray, C., Koivusilta, L., Nislin, M., Sajaniemi, N., Erkkola, M., \& Roos, E. (2019). Children's physical activity and the preschool physical environment: The moderating role of gender. Early Childhood Research Quarterly, 47, 39-48. https://doi.org/10.1016/j.ecresq.2018.10.008

Document status and date:

Published: 01/01/2019

DOI:

10.1016/j.ecresq.2018.10.008

Document Version:

Publisher's PDF, also known as Version of record

Document license:

Taverne

Please check the document version of this publication:

- A submitted manuscript is the version of the article upon submission and before peer-review. There can be important differences between the submitted version and the official published version of record.

People interested in the research are advised to contact the author for the final version of the publication, or visit the DOI to the publisher's website.

- The final author version and the galley proof are versions of the publication after peer review.

- The final published version features the final layout of the paper including the volume, issue and page numbers.

Link to publication

\footnotetext{
General rights rights.

- You may freely distribute the URL identifying the publication in the public portal. please follow below link for the End User Agreement:

www.umlib.nl/taverne-license

Take down policy

If you believe that this document breaches copyright please contact us at:

repository@maastrichtuniversity.nl

providing details and we will investigate your claim.
}

Copyright and moral rights for the publications made accessible in the public portal are retained by the authors and/or other copyright owners and it is a condition of accessing publications that users recognise and abide by the legal requirements associated with these

- Users may download and print one copy of any publication from the public portal for the purpose of private study or research.

- You may not further distribute the material or use it for any profit-making activity or commercial gain

If the publication is distributed under the terms of Article $25 \mathrm{fa}$ of the Dutch Copyright Act, indicated by the "Taverne" license above, 


\title{
Children's physical activity and the preschool physical environment: The moderating role of gender
}

\author{
Suvi Määttäa,*, Jessica Gubbels ${ }^{\mathrm{b}}$, Carola Ray ${ }^{\mathrm{a}}$, Leena Koivusilta ${ }^{\mathrm{c}}$, Mari Nislin ${ }^{\mathrm{d}}$, \\ Nina Sajaniemi ${ }^{\mathrm{e}}$, Maijaliisa Erkkola ${ }^{\mathrm{f}}$, Eva Roos ${ }^{\mathrm{a}, \mathrm{f}, \mathrm{g}}$ \\ a Samfundet Folkhälsan, Folkhälsan Research Center, Topeliuksenkatu 20, 00250 Helsinki, Finland \\ b Maastricht University, Department of Health Promotion, NUTRIM School of Nutrition and Translational Research in Metabolism, PO Box 616, 6200 MD \\ Maastricht, The Netherlands \\ ${ }^{c}$ Department of Social Research, Faculty of Social Sciences, University of Turku, Assistentinkatu 7, 20014, Finland \\ d Department of Early Childhood Education, The Education University of Hong Kong, 10 Lo Ping Road, Tai po, New Territories, Hong Kong, Hong Kong \\ e Faculty of Educational Sciences, University of Helsinki, PL 900014 Helsingin yliopisto, Finland \\ ${ }^{\mathrm{f}}$ Department of Food and Nutrition, University of Helsinki, P.O. Box 66 (Agnes Sjöbergin katu 2), FI-00014, Finland \\ ${ }^{g}$ Department of Public Health, Clinicum, University of Helsinki, PL 20 (Tukholmankatu 8 B), 00014 Helsingin yliopisto, Finland
}

\section{A R T I C L E I N F O}

\section{Article history:}

Received 21 April 2018

Received in revised form 30 August 2018

Accepted 16 October 2018

Available online 5 November 2018

\section{Keywords:}

Preschool

Children

Physical activity

Equipment

\begin{abstract}
A B S T R A C T
The physical environment in preschool, covering all indoor and outdoor equipment, and the surfaces of the preschool yard, may have a large potential for increasing children's physical activity (PA). However, it is less clear which specific physical environmental factors are associated with children's PA. Crosssectional associations between the individual observed items (e.g. fixed and portable equipment, surfaces, terrain in the grounds) as well as composite scores for the PA equipment on the one hand, and children's PA, measured by accelerometers, on the other, were investigated in a sample of 3-6 year old children $(\mathrm{N}=778)$ attending preschool in Finland. Having balance equipment and trampolines in group facilities, having balance equipment, gym mats and sticks in the gym and having skipping ropes, sand and mostly hilly terrain on the outdoor playground were associated with children's higher PA, regardless of gender. On the contrary, having gravel as the terrain in the playground and having a seesaw outdoors were associated with lower PA levels, regardless of gender. Four significant interactions with gender were found, but none of the environmental predictors remained significant in the post-hoc gender-stratified analyses. Variety in PA equipment and playground terrain may be beneficial for increasing children's PA in preschools.
\end{abstract}

(c) 2018 Elsevier Inc. All rights reserved.

\section{Introduction}

Frequent physical activity (PA) in early childhood is associated with better physical, social and psychological health (Timmons et al., 2012). The preschool-age (ages 3-6 years) is a period of particularly rapid development and learning. For instance, competence in multiple motor skills, a prerequisite for PA, is developed in this period (Logan, Kipling Webster, Getchell, Pfeiffer, \& Robinson, 2015; Stodden et al., 2008). The development of motor skills

\footnotetext{
* Corresponding author.

E-mail addresses: suvi.maatta@folkhalsan.fi (S. Määttä), jessica.gubbels@maastrichtuniversity.nl (J. Gubbels), carola.ray@folkhalsan.fi (C. Ray), leena.koivusilta@utu.fi (L. Koivusilta), manislin@eduhk.hk (M. Nislin), nina.sajaniemi@helsinki.fi (N. Sajaniemi), maijaliisa.erkkola@helsinki.fi (M. Erkkola),eva.roos@folkhalsan.fi (E. Roos).
}

requires continuous interaction with a stimulating indoor and outdoor physical environment, including attractive and sufficient space, availability of play equipment (e.g., fixed and portable) and variety of surfaces (e.g., natural elements, artificial coverings) (Wick et al., 2017). Children who develop motor skills earlier are also more likely to be active (Loprinzi, Cardinal, Loprinzi, \& Lee, 2012; Loprinzi, Davis, \& Fu, 2015; Stodden et al., 2008), and better motor skills in early childhood also support children's cognitive and social development (Haapala, 2013). Moreover, higher and more frequent engagement in PA at a preschool-age is associated with the accelerated development of motor skills (Barnett, Salmon, \& Hesketh, 2016; Stodden et al., 2008). However, most preschool children lag behind the required amounts of daily PA, as at least three hours of activity (light, moderate or vigorous) is recommended (Beets, Bornstein, Dowda, \& Pate, 2011; De Craemer et al., 2015; Okely, Trost, Steele, Cliff, \& Mickle, 2009; Pate et al., 2015; Tucker, 2008). There is therefore a need to identify methods for modifying the 
preschool physical environment in order to provide opportunities for all children to improve their motor skills and increase their PA levels.

\subsection{Physical activity in preschool}

Preschool is an important setting for boosting children's daily PA. Previous studies have demonstrated that the preschool setting can account for 14-47 percent of the variance in children's PA after controlling for individual-level factors (Olesen, Kristensen, Korsholm, \& Froberg, 2013; Pate, Pfeiffer, Trost, Ziegler, \& Dowda, 2004; Pate, Mclver, Dowda, Brown, \& Addy, 2008; Reilly, 2010). The majority of children in developed countries attend institutional early education facilities, such as preschools, almost every day of the working week (OECD, organisation for economic Cooperation and Development, 2016), and Finland is no exception (National Institute for Health and Welfare, 2016). About 80\% of Finnish 3 -to-5-year-olds and almost $100 \%$ of six-year-olds, from various socioeconomic and cultural backgrounds, attend full-day preschool (National Institute for Health and Welfare, 2016). This makes the preschool setting a promising place to promote PA. Current national Finnish early-childhood policy also states that preschools should offer stimulating physical environments for children's active play and the development of healthy lifestyles, both indoors and outdoors (Finnish National Agency for Education, 2016). Nonetheless, children are only vigorously physically active for approximately 10 percent of each preschool day in Finland, while they are physically active at any intensity level for less than $50 \%$ of their daily time outdoors (Tammelin et al., 2016). In addition, children's PA in preschools seems to be inadequate to support the development of fundamental motor skills (Iivonen et al., 2016). There is therefore a need for more research on the preschool characteristics that influence children's PA.

\subsection{Environmental factors and level of PA}

Socioecological models state that several factors, such as social interaction between early educators and children, policy regulations, and the physical environment, may influence children's PA in the preschool setting (Bronfenbrenner, 1979; Gubbels, Van Kann, de Vries, Thijs, \& Kremers, 2014; Stokols, 1996). According to a recent review, the aspect most frequently studied in preschools is the physical environment (Tonge, Jones, \& Okely, 2016). The review concludes that a total of 12 physical environment variables are associated with children's PA, the strongest positive associations being with the availability of an outdoor environment in preschool and the size of the play space (Tonge et al., 2016). However, Tonge et al. (2016) conclude that other aspects of the physical environment, such as natural features and surfaces, the presence of hills, shade, portable equipment, and fixed equipment, had either no association or the results were inconclusive (Tonge et al., 2016). Another review focusing on preschool children's playground characteristics concluded that having sufficient space to play and having optimal playground conditions, including an open field, longer recess duration and less supervision, were associated with higher PA levels for preschool children (Broekhuizen, Scholten, \& de Vries, 2014). However, most of these studies have used composite scores to describe the physical environment. These may offer an illustration of the general quality level of the preschool physical environment, but they fail to provide information about which specific environmental factors can be beneficial for increasing PA. Distinct equipment and surfaces can have different associations with children's PA levels. For instance, Gubbels et al. recognized that riding toys and a small play area were associated with lower indoor PA levels (Gubbels, Van Kann, \& Jansen, 2012). In addition, portable slides, fixed swinging equipment and sandboxes were associated with lower outdoor PA levels, whereas the availability of portable jumping equipment and the presence of a structured track in the playground were associated with higher outdoor PA levels (Gubbels et al., 2012). This study was, however, conducted among children aged 2-3 years. Children aged 3-6 years have more developed motor skills, and therefore better capabilities for different types of PA, suggesting different associations between specific physical environmental factors and PA in this age group.

\subsection{The role of gender}

It is well known that preschool-aged boys are more active than girls (Bingham et al., 2016; Hesketh et al., 2016). Although gender is not a modifiable characteristic in behavioral interventions, tailored environmental interventions can be designed when the genderspecific factors associated with PA are recognized. Nevertheless, gender-specific associations between physical environmental factors and children's PA are rarely studied. One study focusing on preschool recess time nevertheless ascertained that hard playground surfaces were associated with higher PA for boys (Cardon, Van Cauwenberghe, Labarque, Haerens, \& De Bourdeaudhuij, 2008). Another study (Hinkley, Salmon, Crawford, Okely, \& Hesketh, 2016) similarly found a number of gender-specific associations between physical environment characteristics and PA. Of these, the number of spaces with natural ground covering, the number of constructed resources and the number of pieces of portable equipment were significantly associated with boys' PA levels, whereas outdoor PA space and total PA space were associated with girls' PA levels (Hinkley et al., 2016).

\subsection{Current study}

This study has two aims: 1) to explore which preschool physical environmental factors (both specific and composite scores) are associated with preschool children's total PA, and 2) whether gender moderates the associations between these factors and preschool children's total PA. We hypothesize that children's gender moderates the associations between the preschool physical environmental factors and children's PA. Children's age and study season are often recognized important factors associated with children's PA (Bingham et al., 2016), and therefore, these factors will be taken into account. In Finland, municipalities are responsible for organizing early education and care services (ECE) based on national guidelines (The Finnish National Agency of Education, 2017), and therefore, municipality level is taken into account.

\section{Methods}

\subsection{Study context}

Each child in Finland has the right to early childhood education. Families pay fees that in full-day provision vary between 0 and $290 €$ per month (as of 2017), depending on the size and income of the family. Most children attend municipal-based preschools, whereas private preschools are rare in Finland. The Finnish ECE model is based on learning by playing, and compulsory pre-primary education in preparation for official schooling begins at the age of six. Learning by playing means for instance that children have free playing times without educator instructions (at least 30 min per each playing time) when children can choose activities they like to be involved in, outdoors or indoors. Children also have compulsory outdoor time, usually twice a day (The Finnish National Agency of Education, 2017). In this study, we use the word 'preschool' to describe formal municipal-based institutional early education provided outside the home. 


\subsection{Participants}

This study is part of the DAGIS (Increased Health and Wellbeing in Preschools) study. More about the study and its procedures can be found elsewhere (Määttä et al., 2015). As part of this overall project, a cross-sectional study was conducted between September 2015 and April 2016. Municipalities with a larger variety in education and income levels with a higher Gini coefficient (the measure of income inequality among the population in a municipality) according to national statistics (National Institute of Health and Welfare, 2016) were selected. In total, eight (75\%) of the 12 municipalities contacted in Southern and Western Finland participated in this study. Preschools were randomly selected within the participating municipalities. The participating preschools were required to have at least one preschool group with 3-to-6-year-olds. In total, 86 of the 169 preschools contacted (56\%) were willing to participate in this study. In total, 16 preschools (19\% of preschools willing to participate) were excluded because their official spoken language was neither Finnish nor Swedish, or because they were open $24 \mathrm{~h}$ a day. Preschool groups providing pre-primary education exclusively for 6-year-old children were also excluded. In addition, we excluded preschools in which less than 30 percent of the children in one preschool group participated in the study. Of the consenting preschools, 20 failed to reach the required 30 percent participation rate. Therefore, the study was conducted in 66 preschools (39\% of those invited). These preschools had a total of 159 preschool groups (range between one to five groups in one preschool) with children aged $3-6$ years.

Of the participating preschools, 3592 parents with children aged 3-6 years were asked to participate. A total of 983 parents agreed to participate in the study ( $27 \%$ consent rate). Of these, 91 parents had a child in a preschool group that failed to achieve the $30 \%$ consent rate and were therefore excluded. In addition, 28 consenting families failed to provide any data. Therefore, a total of 864 children and their parents (24\% of those invited) participated in the crosssectional study. The average age of the participating children was 4 years and 4 months (standard deviation 10 months). Of the participating children, $48 \%$ were girls and $29 \%$ of children had mother with high educational background (at least master's degree). A total of $82 \%$ of children were at least four days a week in the preschool, and $89 \%$ of children were at least $7 \mathrm{~h}$ per day in preschool. The University of Helsinki Ethical Review Board in the Humanities and Social and Behavioral Sciences approved the study procedures.

\section{Measures}

\subsection{Physical environment}

The physical environment was measured using a comprehensive observation instrument that was purposely designed for this study and suitable for the Finnish context. This instrument consisted of a selection of items from the Environment and Policy assessment and Observation Instrument (EPAO) (Ward et al., 2008), items from the National investigation about the PA conditions in Finnish preschools (Ruokonen, Norra, \& Karvinen, 2009), and some additional items developed to meet the aims of this study. All six research assistants in the study were trained to use this instrument by the responsible researcher. Each preschool was simultaneously and independently observed by two research assistants. After each observation, the research assistants discussed their ratings to reach consensus on the findings. The inter-rater reliability between different research assistants was not checked.

Some general guidelines were set for the observations. Assistants were asked to check all the possible closets and rooms in the indoor facilities. Moreover, they were advised to consult early educators if, for instance, they encountered difficulties in opening the outdoor equipment sheds or in observing some items. If preschools lacked a gym but had a separate PA equipment storage room inside (not in the group facilities), the assistants listed the equipment in this storage area as PA equipment in the gym. When observing equipment and PA-promoting elements in the playground, all the possible items were checked. The research assistants were instructed not only to mark all the equipment/surfaces listed on the observation sheet, but also to take account of any other possible items relevant to the observed category and mark them in the open space provided after each category. Based on these openspace items, the following additional equipment was included in the analyses: trampolines, big balls and sticks in group facilities, games and play equipment in the gym, and snow pushers in the playground.

The preschool physical environment related to PA opportunities was assessed according to the following categories: PA equipment in group facilities (10 items), fixed equipment indoors (5 items), Gym in the preschool, PA equipment in the gym (15 items), surfaces in the preschool grounds ( 9 items), terrain in the playground, shady areas in the playground, fixed PA equipment in the preschool yard (9 items), PA-promoting elements in the playground (6 items), and portable equipment in the playground ( 8 items). The items measured in each category are presented in more detail in Table 1.

For PA equipment in the preschool's group facilities, the form had three answer options: yes, in view; yes, in the closet, and none at all. This was recoded as either present (1) or none at all (0). All other equipment was measured as either available (1) or not available (0). When evaluating the terrain and shadiness of the playground, only one option per yard could be selected. Possible answers for the terrain were mostly flat, mostly hilly or a combination of both. The shadiness of the play area was evaluated with three answer options: shadows on the play area, shadows at the sides and no shade at all.

From the individual equipment items, we formed five composite scores to illustrate the total amount of equipment indoors and outdoors. The recommendations of the EPAO observation sheet were followed when forming the composite scores (Bower et al., 2008). Firstly, the composite scores were formed for each equipment category (equipment in group facilities, fixed equipment indoors, equipment in the gym, fixed equipment in the preschool yard, and portable equipment in the playground). The items in each category were summed and divided by the number of items and then multiplied by 10 so that the maximum score in each equipment category was 10 . Secondly, total scores were formed for indoor and outdoor equipment. All the items in each equipment category were summed and divided by the number of items and then multiplied by 10 , so that the maximum score in each equipment category was 10. Next, equipment in the preschool's group facilities, fixed equipment indoors and equipment in the gym were summed to form the adjusted composite score for indoor equipment. Similarly, portable and fixed equipment outdoors were summed to form the adjusted composite score of outdoor equipment.

\subsection{Children's physical activity}

The children wore Actigraph wGT3X-BT accelerometers for seven days, 24-h a day. The research assistants fit the accelerometers around the children's waist in the preschool, and the parents received written instructions about the use of the accelerometer. Preschool-hours were separated from home hours based on the parent-completed diary. In line with previous research, a child should have attended preschool for two days during the measurement week to be included in the study and should have worn his or her accelerometer for a minimum of 240 min during preschool hours (Byun, Beets, \& Pate, 2015; Hinkley et al., 2012; Rich et al., 
Table 1

Descriptive statistics of preschool physical environment items used in the DAGIS study.

\begin{tabular}{|c|c|c|c|c|}
\hline Physical environment context & $\begin{array}{l}\text { Physical environment } \\
\text { item }\end{array}$ & $\%$ of yes & $\begin{array}{l}\text { No. of yes answers on a } \\
\text { preschool group level }\end{array}$ & $\begin{array}{l}\text { Total no. of observed } \\
\text { preschool groups }\end{array}$ \\
\hline \multicolumn{5}{|c|}{ PA equipment in the preschool's group facilities } \\
\hline & Balls & 48.6 & 69 & 142 \\
\hline & Gym mats & 31.4 & 44 & 140 \\
\hline & Spinning equipment & 26.2 & 37 & 141 \\
\hline & Bean bags & 20.4 & 29 & 142 \\
\hline & Parachute & 9.9 & 14 & 141 \\
\hline & Balance equipment & 15.0 & 21 & 140 \\
\hline & Crawling tunnel & 16.4 & 23 & 140 \\
\hline & Trampoline & 5.2 & 7 & 135 \\
\hline & Big balls & 6.7 & 9 & 135 \\
\hline & sticks & 7.4 & 10 & 135 \\
\hline \multicolumn{5}{|l|}{ Fixed equipment indoors } \\
\hline & Soft area for playing & 58.2 & 85 & 146 \\
\hline & Stall bars & 84.9 & 135 & 159 \\
\hline & Climbing wall or other climbing place & 60.1 & 92 & 153 \\
\hline & Floor marks & 70.9 & 107 & 151 \\
\hline & Pool/Water play equipment & 40.3 & 58 & 144 \\
\hline Gym in the preschool & & 72.3 & 115 & 159 \\
\hline \multicolumn{5}{|l|}{ PA equipment in the gym } \\
\hline & Balls & 98.4 & 123 & 125 \\
\hline & Skipping ropes & 91.8 & 112 & 122 \\
\hline & Balance equipment & 92.6 & 113 & 122 \\
\hline & Riding toys & 37.5 & 45 & 120 \\
\hline & Sticks & 91.9 & 114 & 124 \\
\hline & Gym mats & 89.6 & 112 & 125 \\
\hline & Parachute & 87.2 & 109 & 125 \\
\hline & Bean bags & 86.8 & 105 & 121 \\
\hline & Exercise balls & 52.5 & 64 & 122 \\
\hline & Trampoline & 81.7 & 107 & 131 \\
\hline & Crawling tunnel & 77.0 & 94 & 122 \\
\hline & Hoops & 80.0 & 100 & 125 \\
\hline & Movable floor markers & 66.4 & 81 & 122 \\
\hline & Hopper balls & 59.0 & 72 & 122 \\
\hline & Game equipment & 73.8 & 90 & 122 \\
\hline \multicolumn{5}{|l|}{ Surfaces in the preschool grounds } \\
\hline & Asphalt & 49.4 & 78 & 158 \\
\hline & Grass & 79.1 & 125 & 158 \\
\hline & Gravel & 82.3 & 130 & 158 \\
\hline & Sand & 88.0 & 139 & 158 \\
\hline & Safety surfacing & 24.7 & 39 & 158 \\
\hline & Rocks & 34.8 & 55 & 158 \\
\hline & Forest & 6.3 & 10 & 158 \\
\hline & Trees & 72.8 & 115 & 158 \\
\hline & Tiling & 56.3 & 89 & 158 \\
\hline \multicolumn{5}{|l|}{ Terrain on the playground } \\
\hline & Mostly flat & 62.7 & 99 & 158 \\
\hline & Mostly hilly & 2.5 & 4 & 158 \\
\hline & Combination of both & 36.7 & 58 & 158 \\
\hline \multicolumn{5}{|l|}{ Shady areas on the playground } \\
\hline & At the sides & 74.7 & 118 & 158 \\
\hline & In the play areas & 58.2 & 92 & 158 \\
\hline & No shade & 7.6 & 12 & 158 \\
\hline \multicolumn{5}{|c|}{ PA-promoting elements in the playground } \\
\hline & Soccer field & 19.9 & 31 & 156 \\
\hline & Open area suitable for playing & 99.4 & 157 & 158 \\
\hline & Ball wall & 46.8 & 73 & 156 \\
\hline & Basketball hoop & 32.7 & 51 & 156 \\
\hline & Track area for riding toys & 77.7 & 122 & 157 \\
\hline & Outdoor play paintings on the ground & 12.1 & 18 & 149 \\
\hline \multicolumn{5}{|c|}{ Fixed PA equipment in the preschool yard } \\
\hline & Sandbox & 98.7 & 157 & 159 \\
\hline & Playhouse & 37.2 & 58 & 156 \\
\hline & Swings & 100 & 159 & 159 \\
\hline & Spring swings & 74.5 & 117 & 157 \\
\hline & Seesaw & 45.3 & 72 & 159 \\
\hline & Climbing frames & 93.1 & 148 & 159 \\
\hline & Slides & 92.4 & 145 & 157 \\
\hline & Balancing equipment & 66.2 & 102 & 154 \\
\hline & Merry-go-rounds & 17.2 & 26 & 150 \\
\hline
\end{tabular}


Table 1 (Continued)

\begin{tabular}{|c|c|c|c|c|}
\hline Physical environment context & $\begin{array}{l}\text { Physical environment } \\
\text { item }\end{array}$ & $\%$ of yes & $\begin{array}{l}\text { No. of yes answers on a } \\
\text { preschool group level }\end{array}$ & $\begin{array}{l}\text { Total no. of observed } \\
\text { preschool groups }\end{array}$ \\
\hline \multicolumn{5}{|c|}{ Portable PA equipment in the playground } \\
\hline & Balls & 96.2 & 153 & 159 \\
\hline & Skipping ropes & 71.5 & 113 & 158 \\
\hline & Balance equipment & 82.4 & 131 & 159 \\
\hline & Riding toys & 97.5 & 155 & 159 \\
\hline & Sticks & 80.3 & 126 & 157 \\
\hline & Goals & 66.5 & 103 & 155 \\
\hline & Sleds & 94.7 & 144 & 152 \\
\hline & Snow pushers & 69.0 & 107 & 155 \\
\hline
\end{tabular}

2013). Due to children's spontaneous and intermittent activity patterns (Rowlands and Eston, 2007), a 15-s epoch length (defined as sampling interval that summarizes all registered counts during this period) was chosen when downloading data from the Actigraphs. Non-wear time was set at $10 \mathrm{~min}$ of consecutive zeros or more. Evenson cut points were applied (Evenson, Catellier, Gill, Ondrak, \& McMurray, 2008). In this study, we used total PA - from light to vigorous intensity - as an indicator of PA. The cut point for PA was thus at least 101 counts per minute, combining light (between 101 and 2295 counts per minute), moderate (between 2296 and 4011 counts per minute) and vigorous ( 4012 and above per minute) activity (Evenson et al., 2008). Total PA minutes per hour were calculated to account for the varying lengths of time children spent in preschool.

In total, 821 children (95\% of the participants) wore the accelerometer for one week. Of these, 778 (95\%) had sufficient valid hours and days in order to be included in the study. The average wear time during preschool was $419 \mathrm{~min}$ (standard deviation $56 \mathrm{~min}$ ). There were no statistically significant gender, age or socioeconomic status differences between children who had valid data during preschool hours and those who did not (all p values $>0.05$ ).

\subsection{Covariates}

The analyses were adjusted for children's age, gender, and season of measurement. Due to large seasonal variations in weather and its possible influence on children's PA, the season of measurement was used as a covariate. The season of measurement was devided into three groups due to variation in weather conditions ( 1 =September-October, $2=$ November-December, and 3 = January-April). Data regarding $44 \%(n=379)$ of the included children were collected during the months of September and October, 36\% ( $\mathrm{N}=310)$ during November and December, and the remaining $20 \%(\mathrm{~N}=175)$ between January and April.

In addition, multivariate analyses were adjusted for municipality. Municipality was treated as a dummy variable in the analyses. However, all the participating preschools in certain municipalities had all the observed PA equipment in the gym, which meant that no variation existed in the analyses when adjusting for municipality. Therefore, when analyzing the associations between PA equipment in the gym and children's PA, we did not adjust for municipality.

\subsection{Statistical methods}

SPSS version 23 (SPSS Inc.,Chicago, IL, USA) was used for the descriptive statistics and Mann-Whitney U-test. The main analyses were conducted in three steps (Frazier, Tix, \& Barron, 2004). Firstly, in step one, the main effects were examined using linear regression models, clustered within the preschool group, to explore the associations between preschool physical environmental factors and children's PA. Secondly, in step two, moderator effects were examined by additionally including the main effect of gender (the moderator) into the linear regression models, followed by the interaction between each of the independent variables and gender. In case there was a significant moderator effect of gender in step two (defined as $p<0.05$ for the interaction term), post-hoc analyses were performed in step three. The sample was then stratified by gender, and linear regression analyses examining the main effects (in line with step 1) were performed to examine the main associations separately for boys and girls (Frazier et al., 2004). All the linear regression analyses were conducted in Mplus 7.1 (Muthén \& Muthén, 2017). The maximum likelihood estimation with robust standard errors (MLR) was used as an estimator.

\section{Results}

On average, the participants spent $33.5 \mathrm{~min}$ (standard deviation $5.1 \mathrm{~min}$ ) engaged in PA per hour in their preschool. Of this total PA, an average of $27 \mathrm{~min}$ consisted of light activities, $4.5 \mathrm{~min}$ of moderate activities and 2 min of vigorous activities. Boys had an average of $34.3 \mathrm{~min}$ (standard deviation $4.9 \mathrm{~min}$ ) total PA per hour, whereas for girls the average total PA per hour was $32.7 \mathrm{~min}$ (standard deviation 5.3). A Mann-Whitney U-test indicated that boys $(M d n=34.3)$ had significantly higher minutes of total PA per hour than girls $(M d n=32.1), U=4.96, p$ value $<0.001$.

Table 1 displays the descriptive statistics for the physical environment items. All the preschools had swings in the yard. One preschool group lacked an open space suitable for playing in the yard. Similarly, all but two of the preschools groups had balls in the gym and a sandbox in the yard. Due to these non-variations in swings, an open space suitable for playing, balls in the gym and a sandbox in the yard, these items were excluded from the final analyses. Table 2 provides the descriptive statistics for the composite scores of PA equipment.

\subsection{Associations between physical environment and children's total PA}

Table 3 describes the main effects of the associations between the physical environmental factors and the children's PA. Among the preschool group facilities, having balance equipment $(\beta=1.89$, $95 \%$ CI: $0.12,3.65)$ and having a trampoline $(\beta=2.30,95 \% \mathrm{CI}: 0.61$, $3.98)$ were associated with higher PA. Having balance equipment ( $\beta=3.47,95 \%$ CI: $0.64,6.30)$, sticks $(\beta=2.16,95 \% \mathrm{CI}: 0.38,3.94)$ and gym mats ( $\beta=2.08,95 \% \mathrm{CI}: 0.57,3.59)$ in the preschool gym, having skipping rope in the yard ( $\beta=1.59,95 \% \mathrm{CI}: 0.24,2.94)$, sand as a surface in the preschool ground $(\beta=1.66,95 \% \mathrm{CI}: 0.23,3.09)$ and a predominantly hilly landscape in the preschool yard $(\beta=2.07$, $95 \%$ CI: 0.91, 3.23) were all associated with higher PA minutes during preschool hours. By contrast, having gravel as a surface in the preschool grounds $(\beta=-1.87,95 \% \mathrm{CI}:-3.38,-0.36)$ and having a seesaw in the yard $(\beta=-1.63,95 \% \mathrm{CI}:-2.63,-0.63)$ were associated with lower PA minutes during preschool hours. 
Table 2

Descriptive statistics of composite scores for equipment in different contexts in the preschool setting in the DAGIS study.

\begin{tabular}{|c|c|c|c|c|}
\hline Composite score for equipment in certain context & Mean & Standard deviation & Observed score range & Potential score range \\
\hline PA equipment in the group facilities & 2.06 & 2.51 & $0-10$ & $0-10$ \\
\hline Fixed equipment indoors & 2.98 & 1.34 & $0-5$ & $0-5$ \\
\hline PA equipment in the gym & 11.54 & 2.35 & $3-15$ & $0-15$ \\
\hline Adjusted total amount of equipment indoors ${ }^{\mathrm{a}}$ & 12.99 & 5.14 & $0-22.67$ & $0-30$ \\
\hline Fixed PA equipment in the preschool yard & 6.18 & 1.3 & $2-9$ & $0-9$ \\
\hline Portable PA equipment in the playground & 6.41 & 1.28 & $0-8$ & $0-8$ \\
\hline Adjusted total amount of equipment outdoors ${ }^{\mathrm{b}}$ & 14.88 & 2.34 & $4.44-18.89$ & $0-20$ \\
\hline
\end{tabular}

a All the items of PA equipment in the group facilities, fixed equipment indoors or PA equipment in the gym were summed, divided by the number of items, and multiplied by 10 so that maximum score for each item category is 10 .

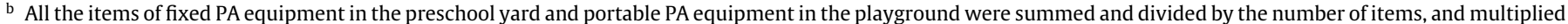
by 10 so that maximum score for each item category is 10 .

\subsection{Moderating effect of gender in associations between physical environment and children's total PA}

Table 3 presents the moderator effect of gender in the associations between the physical environment and children's total PA in preschool. There were four significant moderator effects between gender and physical environmental factors in relation to children's PA: gender interacted with gym mats in the preschool's group facilities $(\beta=1.50,95 \% \mathrm{CI}: 0.19,2.81)$, stall bars indoors $(\beta=-2.21,95 \%$ $\mathrm{CI}:-3.71,-0.71)$, bean bags in the gym $(\beta=2.58,95 \% \mathrm{CI}: 0.23,4.94)$, and slides in the preschool yard $(\beta=-2.46,95 \% \mathrm{CI}:-4.29,-0.62)$. These are presented graphically in Fig. 1. However, the post-hoc analyses revealed that none of the associations remained significant when stratified by gender. Gym mats in the group facilities were not significantly associated with neither girls' $(\beta=-0.02,95 \%$ CI: $-1.53,1.49)$ nor boys' PA ( $\beta=0.98,95 \% \mathrm{CI}:-0.47,2.43)$. Indoor stall bars were not significantly associated with girls' PA $(\beta=0.24$, $95 \% \mathrm{CI}:-1.46,1.95)$ or with boys' PA $(\beta=-1.19,95 \% \mathrm{CI}:-2.63$, 0.25 ) either. Similarly, pea bags in the gym were not significantly associated with girls' $\mathrm{PA}(\beta=-0.03,95 \% \mathrm{CI}$ : $-3.04,2.99)$ or boys' PA ( $\beta=1.58,95 \% \mathrm{CI}:-1.74,4.89)$. Finally, having slides in the preschool yard was not significantly associated with girls' $\mathrm{PA}(\beta=1.61,95 \% \mathrm{CI}$ : $-0.63,3.85)$ or boys' PA $(\beta=-0.23,95 \% \mathrm{CI}:-2.34,1.87)$ either.

\section{Discussion}

This study aimed to explore the associations between children's total PA and various factors in the preschool physical environment. In addition, the study explored whether a child's gender moderated these associations. We hypothesized that gender would moderate the associations between preschool physical environmental factors and children's PA. A range of physical environmental factors were associated with children's PA during preschool hours. Having balance equipment and a trampoline in the group facilities, having balance equipment and gym mats in the gym, and having skipping ropes outdoors were associated with higher PA, regardless of the child's gender. In addition, sand as a surface in the preschool grounds and a predominantly hilly terrain in the preschool yard were also associated with higher PA. Conversely, seesaws and having gravel as an outdoor surface were associated with lower levels of PA. A significant interaction with gender was found for the following items: gym mats in group facilities, stall bars indoors, bean bags in the gym, and slides outdoors. However, perhaps due to insufficient power, none of the variables in the gender-stratified analyses were significantly associated with children's PA.

Our study suggests that it is beneficial to have many different types of equipment both indoors and outdoors in preschools. Nonetheless, equipment related to jumping or balancing skills seems to be particularly associated with higher PA. This finding is in line with Gubbels, who found that portable jumping equipment was positively associated with children's PA in preschools
(Gubbels et al., 2012). Although it was not a research purpose itself, an interesting finding was that only about five percent of preschool groups had trampolines in group facilities. Having a trampoline in a preschool group was associated with higher PA levels. A trampoline may be an indicator of the level of PA equipment in preschools, especially in their group facilities. It may also mean that these preschool's group facilities are more spacious, thereby allowing trampolines to be safely used inside. Early educators have often mentioned the lack of space indoors as a hindrance for increasing indoor PA (Fees, Trost, Bopp, \& Dzewaltowski, 2009; van Zandvoort, Tucker, Irwin, \& Burke, 2010). Similarly, many preschools have safety regulations and rules that limit vigorous activities such as jumping and running (Copeland, Sherman, Kendeigh, Kalkwarf, \& Saelens, 2012). It was outside the scope of this study to investigate the associations between the social environment in preschool and children's PA. However, future research should study in greater depth the potential interaction between the physical environment (e.g. indoor space, equipment) and the social environment (e.g. rules and regulations related to safety issues) and its consequent influence on children's PA levels.

We identified only one piece of equipment, the seesaw, which was associated with lower PA levels. This finding could be explained by the fact that children usually sit when playing on a seesaw. Gubbels similarly found that sandboxes were associated with lower PA levels (Gubbels et al., 2012). However, we were unable to assess the association between sandboxes and children's PA because all the preschools in our study had a sandbox. Furthermore, it should be noted that children's PA was measured by a device worn around the waist, and consequently upper-body movements might have been poorly detected (Hills, Mokhtar, \& Byrne, 2014). Therefore, the associations we found between children's PA and equipment related to throwing and catching may be invalid. Nonetheless, this type of equipment is clearly beneficial for developing fine motor skills, which in turn are beneficial for PA skills (Gallahue, Ozmun, \& Goodway, 2011). In a preschool setting, a wide variety of equipment may therefore be beneficial for children's motor skills and PA levels, but also for children's social and cognitive development (Haapala, 2013).

The results of our study indicated that none of the composite scores for PA equipment was associated with children's PA. When using composite scores for portable and fixed equipment, other studies have produced mixed findings for the associations between equipment and children's PA (Tonge et al., 2016). One reason for such findings may be that these composite scores are constructed from pieces of equipment that are associated with either higher or lower PA. Using composite equipment scores may therefore hide the significant associations between children's PA and individual pieces of equipment. Overall, our findings support the measurement of associations between children's PA and distinct, individual pieces of equipment, which can provide more accurate knowledge for use in future PA-promotion projects. This information 
Table 3


in the DAGIS study.

\begin{tabular}{|c|c|c|c|c|c|c|}
\hline & \multicolumn{6}{|c|}{ Total PA min/hour } \\
\hline & \multicolumn{3}{|c|}{ Main effects ${ }^{a}$} & \multicolumn{3}{|c|}{ Moderator effects ${ }^{\mathrm{b}}$} \\
\hline & $\beta$ & Lower 95\% CI & Upper 95\% CI & $\beta$ & Lower 95\% CI & Upper 95\% CI \\
\hline \multicolumn{7}{|l|}{ PA equipment in the group facilities } \\
\hline Balls $(N=750)$ & 0.35 & -0.95 & 1.64 & 0.84 & -0.49 & 2.17 \\
\hline Gym mats $(N=735)$ & 0.75 & -0.55 & 2.04 & 1.50 & 0.19 & 2.81 \\
\hline Spinning equipment $(\mathrm{N}=732)$ & 0.14 & -0.86 & 1.14 & 0.24 & -1.27 & 1.75 \\
\hline Bean bags $(\mathrm{N}=745)$ & 0.15 & -1.56 & 1.85 & 0.68 & -0.78 & 2.14 \\
\hline Parachute $(\mathrm{N}=737)$ & 1.16 & -1.12 & 3.43 & -1.39 & -3.78 & 1.00 \\
\hline Balance equipment $(\mathrm{N}=730)$ & 1.89 & 0.12 & 3.65 & -0.15 & -1.74 & 1.44 \\
\hline Crawling tunnel $(\mathrm{N}=730)$ & 1.46 & -0.32 & 3.23 & 0.64 & -1.04 & 2.33 \\
\hline Trampoline $(\mathrm{N}=710)$ & 2.30 & 0.61 & 3.98 & -2.05 & -4.50 & 0.39 \\
\hline Big balls $(N=710)$ & 0.80 & -0.67 & 2.28 & 1.14 & -1.64 & 3.92 \\
\hline Sticks $(N=710)$ & -0.04 & -1.80 & 1.72 & 1.54 & -0.64 & 3.73 \\
\hline $\begin{array}{l}\text { Total amount of PA equipment in the } \\
\text { group facilities }(\mathrm{N}=778)\end{array}$ & 0.18 & -0.09 & 0.46 & 0.11 & -0.16 & 0.38 \\
\hline \multicolumn{7}{|l|}{ Fixed equipment indoors } \\
\hline Soft area for playing $(\mathrm{N}=728)$ & 0.73 & -0.75 & 2.21 & -0.27 & -1.68 & 1.34 \\
\hline Stall bars $(\mathrm{N}=778)$ & -0.10 & -1.51 & 1.31 & -2.21 & -3.71 & -0.71 \\
\hline $\begin{array}{l}\text { Climbing wall or other climbing } \\
\text { place }(N=746)\end{array}$ & -1.00 & -2.09 & 0.09 & 0.64 & -0.74 & 2.01 \\
\hline Floor marks $(\mathrm{N}=751)$ & 0.55 & -1.22 & 2.32 & 0.94 & -0.59 & 2.48 \\
\hline Pool/Water play equipment $(\mathrm{N}=706)$ & 0.29 & -1.12 & 1.69 & -0.18 & -1.52 & 1.16 \\
\hline $\begin{array}{l}\text { Total amount of fixed equipment } \\
\text { indoors }(\mathrm{N}=778)\end{array}$ & 0.07 & -0.21 & 0.34 & 0.02 & -0.20 & 0.24 \\
\hline $\begin{array}{l}\text { Total amount of equipment in group } \\
\text { facilities and fixed equipment } \\
\text { indoors }(\mathrm{N}=778)\end{array}$ & 0.15 & -0.08 & 0.38 & 0.07 & -0.16 & 0.30 \\
\hline Gym in the preschool $(\mathrm{N}=778)$ & 0.81 & -1.17 & 2.79 & 0.08 & -1.28 & 2.81 \\
\hline \multicolumn{7}{|l|}{ PA equipment in the gym ${ }^{c}$} \\
\hline Skipping ropes $(\mathrm{N}=571)$ & 1.97 & -0.01 & 3.96 & 0.77 & -1.93 & 3.48 \\
\hline Balance equipment $(\mathrm{N}=568)$ & 3.47 & 0.64 & 6.30 & 1.03 & -1.45 & 3.51 \\
\hline Riding toys $(\mathrm{N}=565)$ & -0.85 & -2.15 & 0.44 & 1.29 & -0.15 & 2.74 \\
\hline Sticks $(N=579)$ & 2.16 & 0.38 & 3.94 & 1.23 & -1.31 & 3.77 \\
\hline Gym mats $(N=584)$ & 2.08 & 0.57 & 3.59 & 1.94 & -0.35 & 4.22 \\
\hline Parachute $(\mathrm{N}=584)$ & -0.59 & -1.72 & 0.54 & -0.55 & -2.63 & 1.54 \\
\hline Bean bags $(\mathrm{N}=562)$ & 0.81 & -1.88 & 3.51 & 2.58 & 0.23 & 4.94 \\
\hline Exercise balls $(\mathrm{N}=570)$ & 0.98 & -0.47 & 2.43 & 0.10 & -1.34 & 1.55 \\
\hline Trampoline $(\mathrm{N}=584)$ & 0.54 & -1.35 & 2.42 & 0.23 & -1.54 & 1.99 \\
\hline Crawling tunnel $(\mathrm{N}=573)$ & 1.61 & -0.08 & 3.31 & 0.73 & -1.24 & 2.70 \\
\hline Hoops $(\mathrm{N}=584)$ & -1.08 & -2.85 & 0.69 & 1.19 & -0.47 & 2.85 \\
\hline Movable floor markers $(\mathrm{N}=568)$ & -0.97 & -2.06 & 0.11 & -0.11 & -1.61 & 1.39 \\
\hline Hopper balls $(\mathrm{N}=574)$ & 0.65 & -0.74 & 2.04 & 1.17 & -0.39 & 2.72 \\
\hline Game equipment $(\mathrm{N}=571)$ & 0.47 & -1.48 & 2.43 & 1.52 & -0.37 & 3.41 \\
\hline $\begin{array}{l}\text { Total amount of PA equipment in the } \\
\operatorname{gym}(\mathrm{N}=503)\end{array}$ & 0.37 & -0.18 & 0.91 & 0.44 & -0.08 & 0.95 \\
\hline $\begin{array}{l}\text { Total amount of equipment in group } \\
\text { facilities, fixed equipment indoors } \\
\text { and equipment in the gym }(\mathrm{N}=778)\end{array}$ & 0.11 & -0.04 & 0.26 & 0.01 & -0.11 & 0.11 \\
\hline \multicolumn{7}{|l|}{ Surfaces in the preschool ground } \\
\hline Asphalt $(\mathrm{N}=770)$ & 0.86 & -0.39 & 2.12 & 0.11 & -1.16 & 1.38 \\
\hline Grass $(N=770)$ & 0.31 & -0.84 & 1.46 & -1.25 & -2.82 & 0.32 \\
\hline Gravel $(\mathrm{N}=770)$ & -1.87 & -3.38 & -0.36 & 0.90 & -0.54 & 2.34 \\
\hline Sand $(N=770)$ & 1.66 & 0.23 & 3.09 & -1.33 & -3.34 & 0.69 \\
\hline Safety surfacing $(N=770)$ & 0.87 & -0.19 & 1.89 & 0.11 & -1.48 & 1.71 \\
\hline Rocks $(\mathrm{N}=770)$ & 0.01 & -1.21 & 1.24 & -0.33 & -1.76 & 1.10 \\
\hline Forest $(\mathrm{N}=770)$ & -0.59 & -1.87 & 0.69 & 0.66 & -1.36 & 2.68 \\
\hline Trees $(\mathrm{N}=770)$ & -0.34 & -2.13 & 1.45 & 0.59 & -0.84 & 2.02 \\
\hline Tiling $(\mathrm{N}=751)$ & 0.80 & -0.47 & 2.08 & 0.89 & -0.36 & 2.13 \\
\hline \multicolumn{7}{|l|}{ Terrain on the playground } \\
\hline Mostly flat $(\mathrm{N}=770)$ & -0.69 & -1.81 & 0.42 & 0.71 & -0.61 & 2.02 \\
\hline Mostly hilly $(\mathrm{N}=770)$ & 2.07 & 0.91 & 3.23 & -0.17 & -1.51 & 1.17 \\
\hline Combination of both $(\mathrm{N}=770)$ & 0.36 & -0.83 & 1.56 & -0.38 & -1.69 & 0.94 \\
\hline \multicolumn{7}{|l|}{ Shady areas on the playground } \\
\hline At the sides $(\mathrm{N}=770)$ & 0.04 & -1.43 & 1.51 & 0.63 & -0.97 & 2.23 \\
\hline In play areas $(\mathrm{N}=770)$ & -0.93 & -2.26 & 0.40 & -0.22 & -1.51 & 1.07 \\
\hline No shade $(N=770)$ & -0.19 & -2.12 & 1.73 & 0.75 & -1.22 & 2.71 \\
\hline \multicolumn{7}{|l|}{$\begin{array}{l}\text { PA promoting elements in the } \\
\text { playground }\end{array}$} \\
\hline Soccer field $(N=768)$ & 0.04 & -1.23 & 1.31 & 0.11 & -1.48 & 1.70 \\
\hline Ball wall $(\mathrm{N}=768)$ & -0.63 & -1.75 & 0.49 & 0.58 & -0.76 & 1.92 \\
\hline Basketball hoop $(\mathrm{N}=763)$ & -0.53 & -1.95 & 0.89 & 0.83 & -0.52 & 2.18 \\
\hline Track area for riding toys $(\mathrm{N}=743)$ & -0.42 & -1.54 & 0.70 & 0.68 & -0.72 & 2.08 \\
\hline Outdoor play paintings on the & 0.15 & -1.41 & 1.70 & -0.62 & -2.38 & 1.14 \\
\hline
\end{tabular}




\begin{tabular}{|c|c|c|c|c|c|c|}
\hline & \multicolumn{6}{|c|}{ Total PA min/hour } \\
\hline & \multicolumn{3}{|c|}{ Main effects ${ }^{\mathrm{a}}$} & \multicolumn{3}{|c|}{ Moderator effects $^{\mathrm{b}}$} \\
\hline & $\beta$ & Lower 95\% CI & Upper 95\% CI & $\beta$ & Lower 95\% CI & Upper 95\% CI \\
\hline \multicolumn{7}{|l|}{$\begin{array}{l}\text { Fixed PA equipment in the preschool } \\
\text { yard }\end{array}$} \\
\hline Playhouse $(\mathrm{N}=763)$ & -0.88 & -2.22 & 0.46 & -0.24 & -1.59 & 1.11 \\
\hline Spring swings $(\mathrm{N}=765)$ & 0.56 & -0.98 & 2.11 & 1.02 & -0.57 & 2.61 \\
\hline Seesaw $(N=778)$ & -1.63 & -2.63 & -0.63 & -0.58 & -1.91 & 0.74 \\
\hline Climbing frames $(\mathrm{N}=778)$ & 0.23 & -1.86 & 2.32 & 0.36 & -2.30 & 3.01 \\
\hline Slides $(N=765)$ & 0.71 & -0.77 & 2.19 & -2.46 & -4.29 & -0.62 \\
\hline Balancing equipment $(\mathrm{N}=756)$ & -0.83 & -2.10 & 0.43 & -0.53 & -1.91 & 0.85 \\
\hline Merry-go-rounds $(\mathrm{N}=730)$ & -0.82 & -2.16 & 0.53 & -0.48 & -1.99 & 1.03 \\
\hline $\begin{array}{l}\text { Total amount of fixed equipment in } \\
\text { the preschool yard }(\mathrm{N}=778)\end{array}$ & -0.35 & -0.71 & 0.01 & -0.14 & -0.56 & 0.31 \\
\hline \multicolumn{7}{|l|}{$\begin{array}{l}\text { Portable PA equipment in the } \\
\text { playground }\end{array}$} \\
\hline Balls $(\mathrm{N}=765)$ & 0.88 & -3.56 & 5.33 & -0.04 & -4.89 & 4.81 \\
\hline Skipping ropes $(\mathrm{N}=778)$ & 1.59 & 0.24 & 2.94 & 0.82 & -0.60 & 2.24 \\
\hline Balance equipment $(\mathrm{N}=778)$ & 1.60 & -0.13 & 3.33 & 0.68 & -1.20 & 2.55 \\
\hline Riding toys $(\mathrm{N}=766)$ & -0.91 & -4.01 & 2.19 & -0.60 & -7.46 & 6.23 \\
\hline Sticks $(N=761)$ & 1.18 & -0.47 & 2.84 & -0.53 & -2.62 & 1.55 \\
\hline Goals $(N=766)$ & -0.38 & -1.73 & 0.97 & 0.27 & -1.23 & 1.77 \\
\hline Sleds $(N=737)$ & -0.41 & -2.38 & 1.53 & -0.25 & -3.73 & 3.24 \\
\hline Snow pushers $(N=749)$ & -1.19 & -2.43 & 0.06 & -1.17 & -2.50 & 0.17 \\
\hline $\begin{array}{l}\text { Total amount of portable equipment } \\
\text { in the playground }(\mathrm{N}=778)\end{array}$ & 0.17 & -0.22 & 0.56 & 0.03 & -0.44 & 0.50 \\
\hline $\begin{array}{l}\text { Total amount of fixed and portable } \\
\text { equipment in the preschool yard } \\
(\mathrm{N}=778)\end{array}$ & -0.07 & -0.31 & 0.17 & -0.01 & -0.30 & 0.28 \\
\hline
\end{tabular}

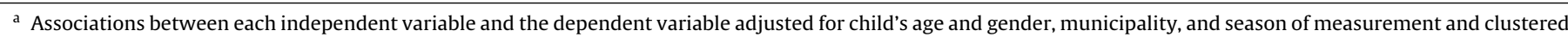
with preschool group.

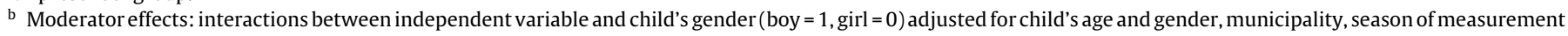
and clustered with preschool group.

c Associations between each independent variable and the dependent variable adjusted for child's age and gender, season of measurement and clustered with preschool

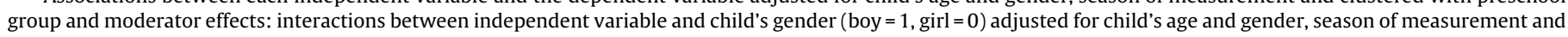
clustered with preschool group.
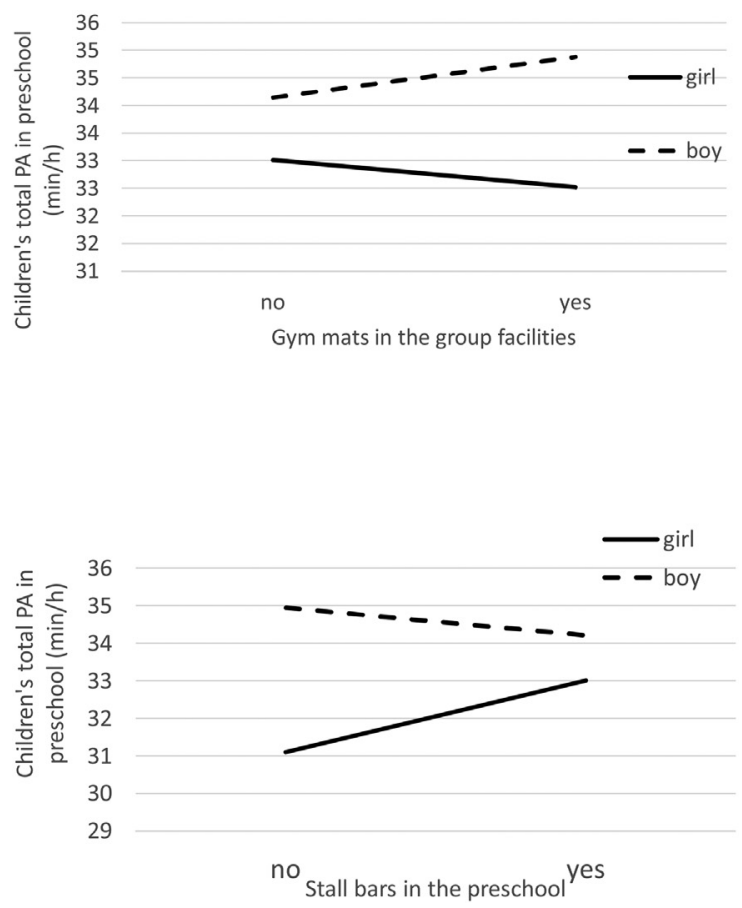

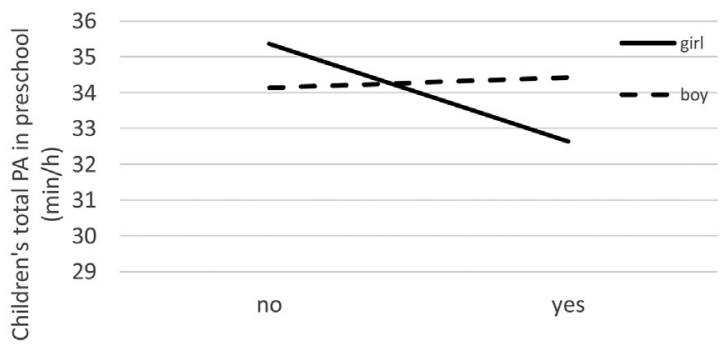

Bean bags in the gym

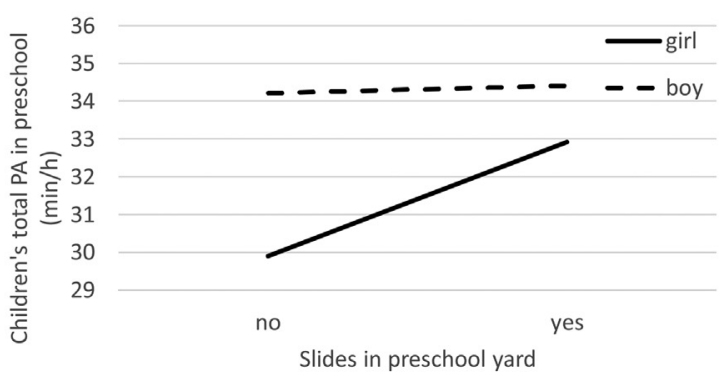

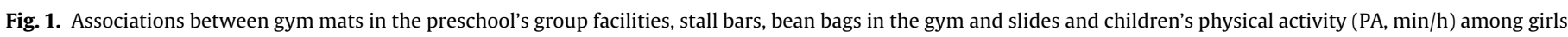
and boys.

may also be valuable when deciding on the availability of equipment in preschools. The availability of multiple types of equipment may be especially relevant in the Finnish-type preschool context, where children have multiple daily free playing times and therefore several options to choose for their activity. 
Our study found that predominantly hilly terrain in the preschool grounds was associated with higher PA. This finding replicates that of a Danish study, which also found that higher PA was associated with a hilly landscape in the preschool yard (Olesen et al., 2013). Many other studies have demonstrated the association between higher PA and having an open area suitable for active play. However, we were unable to include open outdoor space in our final analysis, due to the non-variation in our study sample. Nonetheless, predominantly hilly terrain in the preschool yard may provide similar possibilities for children to be active as open areas. Spacious, hilly environments may inspire children to run, jump and freely engage in 'risky play' (Sandseter \& Kennair, 2011), thereby resulting in greater movement. In contrast to other studies (Cardon et al., 2008; Nicaise, Kahan, \& Sallis, 2011; Sugiyama, Okely, Masters, \& Moore, 2012), hard surfaces in the playground were not associated with children's PA in our study. Instead, sand was associated with higher PA, whereas gravel was associated with lower PA. Another study has suggested that the association between sand and higher PA is due to children's preference for playgrounds with a softer surface (Nasar \& Holloman, 2013). This, in turn, may be because playing in softer materials is easier and because children have less fear of injury. By contrast, gravel may be hard and uncomfortable to play with. When planning future locations for preschools, it is important to ensure that preschool yards provide a variety of natural terrains with height differences and soft surfaces.

Although there were no significant associations between these variables and children's PA once the sample was stratified by gender, the results suggest that fixed equipment such as slides and stall bars are associated with higher levels of PA in girls. This finding is especially important given that some studies have reported that girls are less active than boys (Bingham et al., 2016; Hesketh et al., 2016). Although our sample size was larger than that of many other studies among preschool children (Tonge et al., 2016), further research with even larger sample sizes is needed for a more in-depth investigation of the interaction between gender and PA.

A limitation of this study is the low participation rate of the children (27\%), which may influence on the generalizability of our findings. Many preschools had a wide range of available PA equipment, thereby limiting the variation in equipment levels in our sample and preventing us from testing some potential associations. Furthermore, inter-observer reliability of the observations was not assessed. Although it was based on validated observation instruments, our observation form itself was not validated.

Several accelerometer cut-points exist for measuring preschool children's PA, and using other cut-points might have produced different results. Additionally, outdoor times and indoor times were not separated in our accelerometer data. It is not possible to know whether selection bias occurred, and the most active children participated. We acknowledge that other factors, such as social interaction between early educators, and policy regulations, can affect children's PA. Future research could therefore study the interaction between the physical, social and policy environments of preschool and their associations with children's PA.

\section{Conclusions}

This study furthered understanding of the associations between children's PA and various physical environmental factors in a preschool setting, by using objective measurements and direct observations instead of less valid measures, such as self-report. Due to a quite high participation rate of preschools (56\%), we were able to observe many kinds of preschool settings in a variety of physical environments and regions of the country. This allowed us to study the availability of equipment and the natural environment in several places and ensured the heterogeneity of the preschools studied. Our main findings indicate that having equipment related to jumping or balancing skills, having predominantly hilly terrain in the preschool grounds and having sand as a surface were associated with higher PA. By contrast, seesaws and having gravel as an outdoor surface were associated with lower PA levels.

These results are important for preschool organizations and for municipal technical and planning services when designing the ideal physical environment for promoting children's PA. A variety of equipment in different contexts (e.g. group facilities, outdoors) and a diversity of natural surfaces in the preschool grounds may be essential.

\section{Declarations of interest}

None.

\section{Acknowledgements}

The authors thank the preschools, the preschool personnel, and the parents for their participation in the DAGIS study and the research assistants for data collection. This study was financially supported by the Folkhälsan Research Center, the University of Helsinki, the Ministry of Education and Culture in Finland, Medicinska understödsföreningen för Liv och hälsa, the Academy of Finland (number 288038, number 285439, and number 287288), the Juho Vainio Foundation, the Päivikki and Sakari Sohlberg Foundation, the Signe and Ane Gyllenberg Foundation, and The Finnish Cultural Foundation/South Ostrobothnia Regional Fund.

\section{References}

Barnett, L. M., Salmon, J., \& Hesketh, K. D. (2016). More active pre-school children have better motor competence at school starting age: An observational cohort study. BMC Public Health, 16(1), 1068. http://dx.doi.org/10.1186/s12889-0163742-1

Beets, M. W., Bornstein, D., Dowda, M., \& Pate, R. R. (2011). Compliance with national guidelines for physical activity in U.S. preschoolers: Measurement and interpretation. Pediatrics, 127(4), 658-664. http://dx.doi.org/10.1542/peds. 2010-2021

Bingham, D. D., Costa, S., Hinkley, T., Shire, K. A., Clemes, S. A., \& Barber, S. E. (2016). Physical activity during the early years: A systematic review of correlates and determinants. American Journal of Preventive Medicine, 51(3), 384-402. http:/ dx.doi.org/10.1016/j.amepre.2016.04.022

Bower, J. K., Hales, D. P., Tate, D. F., Rubin, D. A., Benjamin, S. E., \& Ward, D. S. (2008). The childcare environment and children's physical activity. American Journal of Preventive Medicine, 34(1), 23-29. S0749-3797(07)00616-2.

Broekhuizen, K., Scholten, A., \& de Vries, S. I. (2014). The value of (pre)school playgrounds for children's physical activity level: A systematic review. The International Journal of Behavioral Nutrition and Physical Activity, 11(59) http:// dx.doi.org/10.1186/1479-5868-11-59

Bronfenbrenner, U. (1979). The ecology of human development: Experiments by nature and design. Cambridge, MA: Harward University Press.

Byun, W., Beets, M. W., \& Pate, R. R. (2015). Sedentary behavior in preschoolers: How many days of accelerometer monitoring is needed? International Journal of Environmental Research and Public Health, 12(10), 13148-13161. http://dx. doi.org/10.3390/ijerph121013148

Cardon, G., Van Cauwenberghe, E., Labarque, V., Haerens, L., \& De Bourdeaudhuij, I. (2008). The contribution of preschool playground factors in explaining children's physical activity during recess. The International Journal of Behavioral Nutrition and Physical Activity, 5 http://dx.doi.org/10.1186/1479-5868-5-11

Copeland, K. A., Sherman, S. N., Kendeigh, C. A., Kalkwarf, H. J., \& Saelens, B. E. (2012). Societal values and policies may curtail preschool children's physical activity in child care centers. Pediatrics, 129(2), 265-274. http://dx.doi.org/10. 1542/peds.2011-2102

De Craemer, M., Lateva, M., Iotova, V., De Decker, E., Verloigne, M., De Bourdeaudhuij, I., ... \& ToyBox-study group. (2015). Differences in energy balance-related behaviours in European preschool children: The ToyBox-study. PLoS One, 10(3) http://dx.doi.org/10.1371/journal.pone.0118303

Evenson, K. R., Catellier, D. J., Gill, K., Ondrak, K. S., \& McMurray, R. G. (2008). Calibration of two objective measures of physical activity for children. Journal of Sports Sciences, 26(14), 1557-1565. http://dx.doi.org/10.1080/ 02640410802334196; 10.1080/02640410802334196

Fees, B., Trost, S., Bopp, M., \& Dzewaltowski, D. A. (2009). Physical activity programming in family child care homes: Providers' perceptions of practices and barriers. Journal of Nutrition Education and Behavior, 41(4), 268-273. http:// dx.doi.org/10.1016/j.jneb.2008.01.013 
Finnish National Agency for Education. (2016). National core curriculum for early childhood education and care. Helsinki: Finnish National Agency for Education.

Frazier, P., Tix, A. P., \& Barron, K. (2004). Testing moderator and mediator effects in counseling psychology research. Journal of Counseling Psychology, 51(1), 115-134. http://dx.doi.org/10.1037/0022-0167.51.1.115

Gallahue, D. L., Ozmun, J. C., \& Goodway, J. D. (2011). Understanding motor development: Infants, children, adolescents, adults (7th edition). Boston, United States: McGraw-Hill.

Gubbels, J. S., Van Kann, D. H., \& Jansen, M. W. (2012). Play equipment, physical activity opportunities, and children's activity levels at childcare. Journal of Environmental and Public Health, 326520. http://dx.doi.org/10.1155/2012/ 326520

Gubbels, J. S., Van Kann, D. H., de Vries, N. K., Thijs, C., \& Kremers, S. P. (2014). The next step in health behavior research: The need for ecological moderation analyses - an application to diet and physical activity at childcare. The International Journal of Behavioral Nutrition and Physical Activity, 11(1) http:// dx.doi.org/10.1186/1479-5868-11-52

Haapala, E. A. (2013). Cardiorespiratory fitness and motor skills in relation to cognition and academic performance in children. A review. Journal of Human Kinetics, 36, 55-68. http://dx.doi.org/10.2478/hukin-2013-0006

Hesketh, K. R., O'Malley, C., Mazarello Paes, V. M. H., Summerbell, C., Ong, K. K. Lakshman, R., \& van Sluijs, E. M. F. (2016). Determinants of change in physical activity in children 0-6 years of age: A systematic review of quantitative literature. Sports Medicine, 1-26. http://dx.doi.org/10.1007/s40279-016-0656-

Hills, A. P., Mokhtar, N., \& Byrne, N. M. (2014). Assessment of physical activity and energy expenditure: An overview of objective measures. Frontiers in Nutrition 1, 5. http://dx.doi.org/10.3389/fnut.2014.00005

Hinkley, T., O'Connell, E., Okely, A. D., Crawford, D., Hesketh, K., \& Salmon, J. (2012). Assessing volume of accelerometry data for reliability in preschool children. Medicine and Science in Sports and Exercise, 44(12), 2436-2441. http://dx.doi. org/10.1249/MSS.0b013e3182661478

Hinkley, T., Salmon, J., Crawford, D., Okely, A. D., \& Hesketh, K. D. (2016). Preschool and childcare center characteristics associated with children's physical activity during care hours: An observational study. The International Journal of Behavioral Nutrition and Physical Activity, 13(1), 117. http://dx.doi.org/10.1186/ s12966-016-0444-0

Iivonen, S., Sääkslahti, A., Mehtälä, A., Villberg, J., Soini, A., \& Poskiparta, M. (2016). Directly observed physical activity and fundamental motor skills in four-year-old children in day care. European Early Childhood Education Research Journal, 24(3), 398-413. http://dx.doi.org/10.1080/1350293X.2016.1164398

Logan, S. W., Kipling Webster, E., Getchell, N., Pfeiffer, K. A., \& Robinson, L. E. (2015). Relationship between fundamental motor skill competence and physical activity during childhood and adolescence: A systematic review. Kinesiology Review, 4(4), 416-426. http://dx.doi.org/10.1123/kr.2013-0012

Loprinzi, P. D., Cardinal, B. J., Loprinzi, K. L., \& Lee, H. (2012). Benefits and environmental determinants of physical activity in children and adolescents. Obesity Facts, 5(4), 597-610. http://dx.doi.org/10.1159/000342684

Loprinzi, P. D., Davis, R. E., \& Fu, Y. C. (2015). Early motor skill competence as a mediator of child and adult physical activity. Preventive Medicine Reports, 2 833-838. http://dx.doi.org/10.1016/j.pmedr.2015.09.015

Määttä, S., Lehto, R., Nislin, M., Ray, C., Erkkola, M., Sajaniemi, N., \& Roos, E. (2015). Increasedhealth and wellbeing in preschools (DAGIS): rationale and design for arandomized control. BMC Public Health, 15(1), 402.

Muthén, \& Muthén. (2017). MPLUS (Version 8.1). Los Angeles, CA: Computer Software].

Nasar, J. L., \& Holloman, C. H. (2013). Playground characteristics to encourage children to visit and play. Journal of Physical Activity E Health, 10(8), 1201-1208, 2011-0421.

National Institute for Health and Welfare. (2016). Lasten päivähoito [children's early childhood education and care 2015]. Statistical Report 21/2019, 29.12.2016.

National Institute of Health and Welfare. (2016). Welfare compass for monitoring regional welfare. Retrieved from http://www.hyvinvointikompassi.fi/en/web/ hyvinvointikompassi/etusivu

Nicaise, V., Kahan, D., \& Sallis, J. F. (2011). Correlates of moderate-to-vigorous physical activity among preschoolers during unstructured outdoor play periods. Preventive Medicine, 53(4-5), 309-315. http://dx.doi.org/10.1016/j. ypmed.2011.08.018

OECD, Orgnization for Economic Cooperation and Development. (2016). Family database, PF3.2. enrolment in childcare and pre-schools. OECD-Social Policy Division-Directorate of Employment, Labour, and Social affairs.. Retrieved from http://www.oecd.org/els/family/database.htm

Okely, A. D., Trost, S. G., Steele, J. R., Cliff, D. P., \& Mickle, K. (2009). Adherence to physical activity and electronic media guidelines in Australian pre-school children. Journal of Paediatrics and Child Health, 45(1-2), 5-8. http://dx.doi.org/ $10.1111 / \mathrm{j} .1440-1754.2008 .01445 . x$
Olesen, L. G., Kristensen, P. L., Korsholm, L., \& Froberg, K. (2013). Physical activity in children attending preschools. Pediatrics, 132(5), e1310-e1318. http://dx.doi. org/10.1542/peds.2012-3961

Pate, R. R., Pfeiffer, K. A., Trost, S. G., Ziegler, P., \& Dowda, M. (2004). Physical activity among children attending preschools. Pediatrics, 114(5), 1258-1263, $114 / 5 / 1258$.

Pate, R. R., McIver, K., Dowda, M., Brown, W. H., \& Addy, C. (2008). Directly observed physical activity levels in preschool children. The Journal of School Health, 78(8), 438-444. http://dx.doi.org/10.1111/j.1746-1561.2008.00327.x

Pate, R. R., O'Neill, J. R., Brown, W. H., Pfeiffer, K. A., Dowda, M., \& Addy, C. L. (2015). Prevalence of compliance with a new physical activity guideline for preschool-age children. Childhood Obesity (Print), 11(4), 415-420. http://dx.doi. org/10.1089/chi.2014.0143

Reilly, J. J. (2010). Low levels of objectively measured physical activity in preschoolers in child care. Medicine and Science in Sports and Exercise, 42(3), 502-507. http://dx.doi.org/10.1249/MSS.0b013e3181cea100

Rich, C., Geraci, M., Griffiths, L., Sera, F., Dezateux, C., \& Cortina-Borja, M. (2013). Quality control methods in accelerometer data processing: defining minimum wear time. PLoS One, 8(6), e67206. http://dx.doi.org/10.1371/journal.pone. 0067206

Rowlands, A. V., \& Eston, R. G. (2007). The Measurement and Interpretation of Children's Physical Activity. Journal of Sports Science and Medicine, 6(September 1 (3)), 270-276

Ruokonen, R., Norra, J., \& Karvinen, H. (2009). Valtakunnallinen selvitys päiväkotien liikuntaolosuhteista. (The National investigation about the PA conditions in Finnish preschools). Helsinki: Young Finland ry/Finnish Olympic Committee. Retrieved from http://www.sport.fi/kirjasto/teos/paivakotienliikuntaolosuhteet? $\mathrm{p}=$ kihu\&t=tutkimukset

Sandseter, E. B., \& Kennair, L. E. (2011). Children's risky play from an evolutionary perspective: The anti-phobic effects of thrilling experiences. Evolutionary Psychology: An International Journal of Evolutionary Approaches to Psychology and Behavior, 9(2), 257-284, epjournal-1440.

Stodden, D. F., Goodway, J. D., Langendorfer, S. J., Roberton, M. A., Rudisill, M. E., Garcia, C., \& Garcia, L. E. (2008). A developmental perspective on the role of motor skill competence in physical activity: An emergent relationship. Quest, 60(2), 290-306. http://dx.doi.org/10.1080/00336297.2008.10483582

Stokols, D. (1996). Translating social ecological theory into guidelines for community health promotion. American Journal of Health Promotion, 10(4), $282-298$.

Sugiyama, T., Okely, A. D., Masters, J. M., \& Moore, G. T. (2012). Attributes of child care centers and outdoor play areas associated with preschoolers' physical activity and sedentary behavior. Environment and Behavior, 44(3), 334-349. http://dx.doi.org/10.1177/0013916510393276

Tammelin, T. H., Aira, A., Hakamaki, M., Husu, P., Kallio, J., Kokko, S., . . \& \& Kamppi, K. (2016). Results from Finland's 2016 report card on physical activity for children and youth. Journal of Physical Activity \& Health, 13(11 Suppl 2) S157-S164. http://dx.doi.org/10.1123/jpah.2016-0297

The Finnish National Agency of Education.Early childhood education and care. Retrieved from http://www.oph.fi/english/education_system/early_childhood_ education.

Timmons, B. W., Leblanc, A. G., Carson, V., Connor Gorber, S., Dillman, C., Janssen, I., ... \& Tremblay, M. S. (2012). Systematic review of physical activity and health in the early years (aged 0-4 years). Applied Physiology, Nutrition, and Metabolism = Physiologie Appliquee, Nutrition Et Metabolisme, 37(4), 773-792. http://dx.doi.org/10.1139/h2012-070

Tonge, K. L., Jones, R. A., \& Okely, A. D. (2016). Correlates of children's objectively measured physical activity and sedentary behavior in early childhood education and care services: A systematic review. Preventive Medicine, 89, 129-139. http://dx.doi.org/10.1016/j.ypmed.2016.05.019

Tucker, P. (2008). The physical activity levels of preschool-aged children. A systematic review Early Childhood Res. Q., 23(4), 547-558. http://dx.doi.org/10. 1016/j.ecresq.2008.08.005

van Zandvoort, M., Tucker, P., Irwin, J. D., \& Burke, S. M. (2010). Physical activity at daycare: Issues, challenges and perspectives. Early Years, 30(2), 175-188. http://dx.doi.org/10.1080/09575141003667282

Ward, D., Hales, D., Haverly, K., Marks, J., Benjamin, S., Ball, S., \& Trost, S. (2008). An instrument to assess the obesogenic environment of child care centers. American Journal of Health Behavior, 32(4), 380-386. http://dx.doi.org/10.5555/ ajhb.2008.32.4.380

Wick, K., Leeger-Aschmann, C. S., Monn, N. D., Radtke, T., Ott, L. V., Rebholz, C. E. . \& Kriemler, S. (2017). Interventions to promote fundamental movement skills in childcare and kindergarten: A systematic review and meta-analysis. Sports Med. (Auckland, N.Z.), 47(October (10)), 2045-2068. 